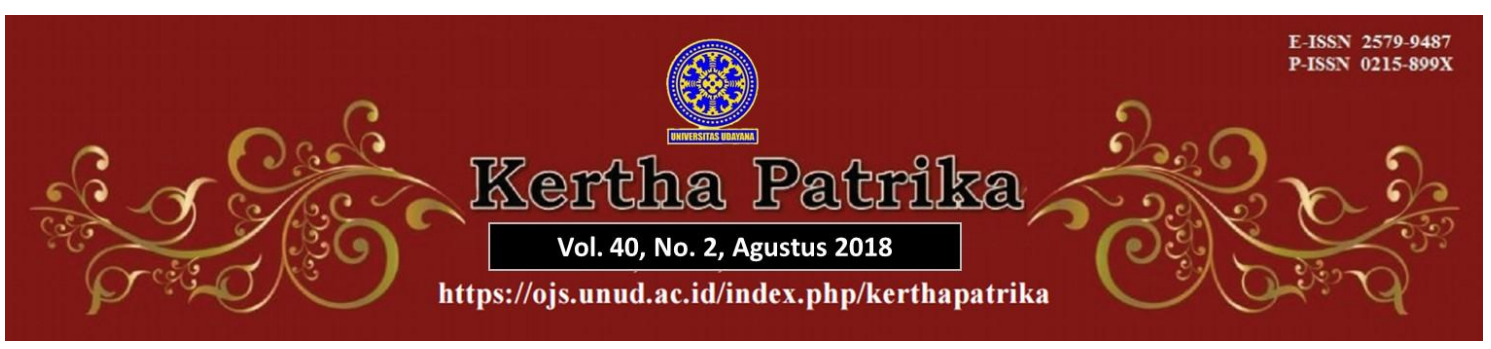

\title{
Penguatan Eksistensi Bahasa Tana dalam Upaya Perlindungan Hukum Bahasa Daerah sebagai Warisan Budaya Bangsa
}

\author{
Teng Berlianty, ${ }^{1}$ Agustima Balik ${ }^{2}$
}

${ }^{1}$ Fakultas Hukum Universitas Pattimura, E-mail : berliantyt@yahoo.com

${ }^{2}$ Fakultas Hukum Universitas Pattimura, E-mail : balikgusti@yahoo.co.id

\begin{tabular}{l}
\hline Info Artikel \\
\hline Masuk: 18 Juni 2018 \\
Diterima: 30 Agustus 2018 \\
Terbit: 31 Agustus 2018 \\
Keywords: \\
Strengthening the existence of \\
Bahasa Tana; legal protection; \\
national culture \\
\\
\\
\\
Dorresponding Author: \\
Teng Berlianty, E-mail: \\
10.24843/KP.2018.v40.i02.p04 \\
Kata kunci: \\
Penguatan eksistensi bahasa \\
tana; perlindungan hukum; \\
warisan bangsa \\
Coo.com
\end{tabular}

\begin{abstract}
The objective of the study is to understand laws protecting local languages by way of strengthening the existence of Moluccas 'bahasa tana' as a national cultural heritage. The research is conducted using the normative-juridical method with a descriptive-analytical approach, in which the problem is tackled from a statute and conceptual stand point. Collecting of legal materials is done in two ways, literature research and field reseaech. Analysis of data is executed qualitatively, considering the descriptive nature of the materials collected.From the legal anthropological approach, these local languages need to gain protection under the law, to allow their preservation. The law on the preservation of local language is based on article 321945 constitution, stated "The Government shall advance the national culture", in this case, local languages as the national cultural treasures. By the aforementioned law, the nation provides opportunities and discretion to the people in the effort to develop and preserve their local culture, including the variety of local languages. In Government Regulation Number 57 Year 2014 Concerning Development, Coaching and Protection of Language and Literature, also enhancement of Indonesian purpose explaining that local languages has a very large function among others as the former of nation tribal personality, affirmation of regional identity, as a tool of disclosure and also enhancement of literature and local culture in the frame of Indonesianness.
\end{abstract}

Abstrak penelitian ini adalah untuk mengetahui
perlindungan hukum terhadap bahasa daerah melalui penguatan eksistensi bahasa tana Maluku sebagai warisan budaya bangsa.Metode penelitian yang digunakan adalah metode penelitian yuridis normatif dengan sifat penelitiannya deskritif analitis, dimana pendekatan masalah yang digunakan adalah pendekatan perundangundangan dan pendekatan konseptual. Pengumpulan bahan hukum dilakukan dengan dua cara yaitu dengan penelitian kepustakaan dan penelitian lapangan. Analisa bahan hukum dilakukan secara kualitatif mengingat bahan hukum yang terkumpul bersifat deskritif. Jika dilihat dari prespektif antropologi hukum, bahasa tana ini perlu mendapatkan perlindungan hukum agar tidak mengalami kepunahan secara keseluruhan. Pelindungan terhadap 


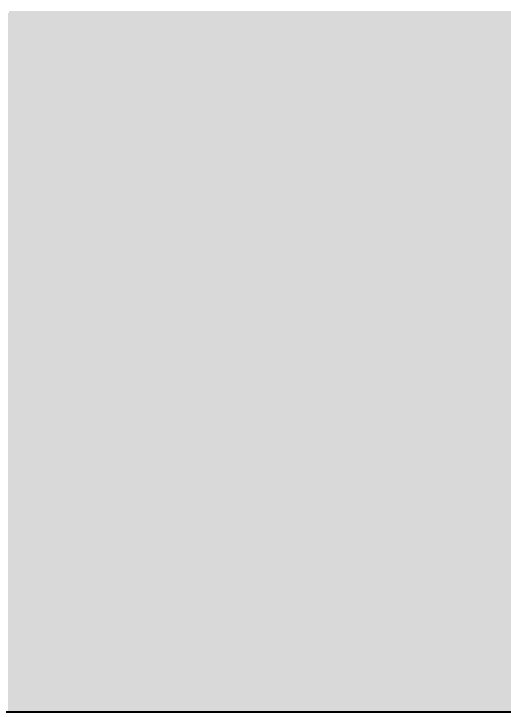

bahasa daerah didasarkan pada amanat Pasal 32 Ayat 2 UUD 1945, yang menyatakan bahwa negara menghormati dan memelihara bahasa daerah sebagai kekayaan budaya nasional. Dengan ayat itu, negara memberi kesempatan dan keleluasaan kepada masyarakat untuk melestarikan dan mengembangkan bahasanya sebagai bagian dari kebudayaannya masing-masing. Dalam Peraturan Pemerintah Nomor 57 Tahun 2014 tentang pengembangan, Pembinaan dan Perlindungan Bahasa dan sastra serta peningkatan fungsi bahasa Indonesia juga menjelaskan bahwa bahasa daerah memiliki fungsi yang sangat besar diantaranya sebagai pembentuk kepribadian suku bangsa, peneguh jati diri kedaerahan, sarana pengungkapan serta pengembangan sastra dan budaya daerah dalam bingkai keindonesiaan.

\section{PENDAHULUAN}

Sebagai etnis yang multikultur, bangsa Indonesia merupakan himpunan berbagai jenis masyarakat yang berbeda ragam sifat karakter dan adat budayanya. ${ }^{1}$ Salah satu bukti dari pernyataan tersebut ialah Indonesia sangat kaya dengan bahasa dan sastra daerah. Kekayaan itu di satu sisi merupakan kebanggaan, tetapi di sisi lain menjadi tugas yang tidak ringan, terutama apabila memikirkan bagaimana cara melindungi, menggali manfaat, dan mempertahankan keberagamannya. Bahasa daerah merupakan bahasa ibu, sedangkan bahasa Indonesia merupakan bahasa nasional dan bahasa resmi Bangsa Indonesia. Bahasa daerah merupakan salah satu warisan budaya bangsa.

Dalam Ethnoloque, disebutkan bahwa terdapat 726 bahasa di Indonesia. ${ }^{2}$ Sebagian masih akan berkembang, tetapi tidak dapat diingkari sebagian besar bahasa itu akan punah. Di Indonesia terdapat lebih dari 640 bahasa daerah yang di dalamnya terdapat sekitar 154 bahasa yang harus diperhatikan, yaitu sekitar 139 bahasa terancam punah dan 15 bahasa yang benar-benar telah mati. ${ }^{3}$ Bahasa yang terancam punah terdapat di Kalimantan (1 bahasa), Maluku (22 bahasa), Papua Barat dan Kepulauan Halmahera (67 bahasa), Sulawesi (36 bahasa), Sumatra (2 bahasa), serta Timor-Flores dan BimaSumbawa (11 bahasa). Sementara itu, bahasa yang telah punah berada di Maluku (11 bahasa), Papua Barat dan Kepulauan Halmahera, Sulawesi, serta Sumatera (masingmasing 1 bahasa). ${ }^{4}$

Hilangnya daya hidup bahasa daerah pada umumnya disebabkan oleh pindahnya orang desa ke kota untuk mencari penghidupan yang dianggap lebih layak dan perkawinan antar etnis yang banyak terjadi di Indonesia. Masyarakat perkotaan, yang pada umumnya merupakan masyarakat multietnis atau multilingual, memaksa

\footnotetext{
${ }^{1}$ Purwaningsih, E. (2012). Perlindungan Hukum Terhadap Kekayaan Intelektual Warisan Bangsa Sebagai Implikasi Yuridis Nilai-Nilai Kebangsaan Menuju Ketahanan Nasional. Jurnal NEGARAWAN Kementerian Sekretariat Negara RI, 26 (3), h.2

${ }^{2}$ Badan Pengembangan Dan Pembinaan Bahasa Kementerian Pendidikan Dan Kebudayaan, Perlindangan Bahasa Daerah Dalam Kerangka Kebijakan Nasional Kebahasaan, www.google.com. (diakses 30 Juni 2017).

${ }^{3}$ Wurm, Stephen A (ed). (2001). Atlas of the world's Language in Danger of Disapearing, Paris: UNESCO Publishing, dalam Badan Pengembangan Dan Pembinaan Bahasa Kementerian Pendidikan Dan Kebudayaan, Perlindangan Bahasa Daerah Dalam Kerangka Kebijakan Nasional Kebahasaan, www.google.com. (diakses 30 Juni 2017).

${ }^{4}$ Ibid.
} 
seseorang harus meninggalkan bahasa etnisnya dan menuju bahasa nasional. Pada umumnya, bahasa etnis setiap orang tua akan ditinggalkan dan bahasa Indonesia kemudian digunakan dalam keluarga itu karena bahasa itu dianggap sebagai bahasa yang dapat menghubungkan mereka secara adil. Kepunahan bahasa-bahasa daerah merupakan fenomena yang perlu dicermati dan disikapi secara serius dan bijaksana. Berbagai faktor yang dapat menyebabkan kepunahan bahasa sebagaimana dikemukakan di atas tampaknya dapat dikategorikan ke dalam dua bagian besar yaitu faktor alamiah dan faktor non-alamiah. Faktor alamiah yang tidak dapat dihindari kejadiannya dapat berupa bencana alam (natural disaster), pengaruh bahasa mayoritas, komunitas bahasa yang bilingual atau multilingual, pengaruh globalisasi, migrasi (migration), perkawinan antaretnik (intermarriage). Sementara itu, kurangnya penghargaan terhadap bahasa daerah, kurangnya intensitas pemakaian bahasa daerah, pengaruh faktor ekonomi, dan pengaruh pemakaian bahasa Indonesia merupakan faktor-faktor penyebab yang bersifat non-alamiah. ${ }^{5}$

Menurut Keraf sebagaimana yang dikutip oleh Ahmad Nasir Biasane, ${ }^{6}$ kearifan lokal adalah semua bentuk pengetahuan, keyakinan, pemahaman atau wawasan serta adat kebiasaan atau etika yang menuntun perilaku manusia dalam kehidupan di dalam komunitas ekologis. Sehingga kearifan lokal bukan hanya menyangkut pengetahuan atau pemahaman masyarakat adat tentang manusia dan bagaimana relasi yang baik diantara manusia, melainkan juga menyangkut pengetahuan, pemahaman, adat kebiasaan tentang manusia, alam dan bagaimana relasi diantara semua penghuni komunitas ekologi. Seluruh kearifan lokal ini dihayati, dipraktekkan, diajarkan dan diwariskan dari satu generasi ke generasi lain yang sekaligus membentuk pola perilaku manusia sehari-hari, baik terhadap sesama manusia maupun terhadap alam dan yang gaib. Bahasa daerah dipakai untuk membangun relasi diantara semua penghuni suatu komunitas dalam kehidupan sehari-hari, bukan saja pada upacaraupacara adatatau acara adat istiadat lainnya.

Mengingat bahasa daerah merupakan salah unsur kebudayaan, maka sudah selayaknya negara harus mempertahankan budaya warga negaranya. Hal tersebut dilakukan agar bangsa Indonesia tidak kehilangan jati diri dan identitas bangsanya yang disebabkan oleh masuknya dampak negatif kebudayaan asing yang mempengaruhi pola kehidupan bangsa Indonesia. Masa depan bangsa kita sekarang yang juga sedang menghadapi pengaruh atau lebih tepat terjangan kebudayaan Barat dalam hampir seluruh bidang kehidupan kita sebagai bangsa Indonesia. ${ }^{7}$

Pemerintah telah mengeluarkan Undang-Undang Nomor 24 Tahun 2009 tentang Bendera, Bahasa, Lambang Negara serta Lagu Kebangsaan yang didalamnya mengatur pentingnya perlindungan, pelestarian dan pembinaan bahasa daerah. Dalam UndangUndang Nomor 24 Tahun 2009 didefinisikan bahwa bahasa daerah merupakan bahasa yang digunakan secara turun-temurun oleh warga negara Indonesia di daerah-daerah di Wilayah Negara Kesatuan Republik Indonesia. Dengan demikian, bahasa daerah diibaratkan sebagai jati diri masyarakat indonesia yang beragam suku.

Di seluruh Maluku dari Kei sampai Ternate terdapat bahasa-bahasa daerah asli Maluku yang disebut dengan "Bahasa Tana", bahasa ini tidak hanya terdapat pada

\footnotetext{
${ }^{5}$ Tondo, F.H. (2009). Kepunahan Bahasa-Bahasa Daerah: Faktor Penyebab Dan Implikasi Etnolinguistis. Jurnal Masyarakat \& Budaya, 11(2), h.293.

${ }^{6}$ Biasane, A.N. (2004). Kontruksi Kearifan Tradisional Dalam Pengelolaan Perikanan Berkelanjutan, Makalah Pengantar ke Filsafat Sains Sekolah Pasca Sarjana/S3, Institut Pertanian Bogor. h.3.

${ }^{7}$ Islamuddin. (2014). Pengembangan Budaya Suku Talang Mamak Sebagai Nilai-Nilai Kearifan Lokal Dalam Bagian Civic Culture (Studi Etnografi Pada Masyarakat Suku Talang Mamak Di Kecamatan Rakit Kulim, Kabupaten Indragiri Hulu, Propinsi Riau) Kjpis. Jurnal Pendidikan Ilmu Sosial, 23(2), h.56.
} 
beberapa daerah atau desa-desa akan tetapi bahasa ini merupakan bahasa ibu orang Maluku. Dalam bahasa Ambon, "tana" bisa berarti tanah, bisa berarti juga ditujukan kepada tanah leluhur di pulau Nusa Ina, sehingga bahasa tana dapat diartikan sebagai bahasa asli orang Maluku. Bahasa tana bermula dari pedalaman Nusa Ina yang dianggap sebagai pulau pertama orang Maluku berdiam sebelum tersebar ke seantero Maluku. Sedangkan bahasa Ambon atau bahasa sehari-hari orang Maluku disebut dengan bahasa Melayu Ambon, yang dipergunakan hampir oleh sebagian besar orang Maluku dalam komunikasi sehari-hari. ${ }^{8}$

Sampai sekarang tidak kurang dari 117 bahasa tana yang terdapat di seluruh Maluku, dan ada beberapa yang mengalami kepunahan, kebanyakan bahasa tana yang mengalami kepunahan adalah bahasa tana yang dipergunakan oleh desa-desa Kristen baik di pulau Ambon maupun sebagian kecil pulau Seram. Bahasa tana pada komunitas Kristen pernah dicatat oleh Geogius Rumphius pada tahun 1987, yaitu di desa Hative dan Hitu, dalam laporannya ia mengatakan bahwa bahasa Ambon (Hative dan Hitu) sudah punah tanpa jejak sampai sekarang. Sedangkan pada komunitas Islam masih bertahan. Hal ini dibuktikan dengan diluncurkannya Kamus Bahasa Tana Asilulu-Inggris oleh James T. Collins. ${ }^{9}$

Dalam sebuah acara diskusi yang diselenggarakan oleh TVRI Stasiun Ambon, Kepala Kantor Bahasa Propinsi Maluku mengemukakan bahwa baru 48 bahasa tana yang teridentifikasi masih eksis dipergunakan oleh masyarakat Maluku dalam komunikasi sehari-hari misalnya di Hitu dan Maluku Tenggara. Itu artinya masih banyak bahasa tana yang belum diketahui masih eksis dipergunakan atau sudah punah. Bahasa tana akan nampak terlihat atau dipergunakan jika ada upacara-upacara adat atau pertunjukan-pertunjukan adat istiadat yang memang harus dipandu menggunakan bahasa tana. Padahal bahasa tana adalah bukti dari kepribadian dan jati diri orang Maluku juga sebagai kekayaan budaya nasional yang harus dijaga dan dilestarikan. Namun untuk membangun dan menata dan membangun kesadaran hukum dan prilaku budaya diperlukan pembangunan moral secara berkesinambungan, yang tentu saja harus sinergi dengan pembanugnan masyarakat sejahtera. Rendah atau lemahnya tingkat kesadaran hukum di Indonesia tidak hanya disandang oleh kawula rakyat saja tetapi juga pengusa. ${ }^{10}$

Penggunaan bahasa tana secara terus-menerus sesungguhnya merupakan salah satu cara untuk melestarikan adat istiadat dan budaya orang Maluku. Ketika diperhadapkan dengan persoalan punahnya sebagian besar bahasa tana di Maluku sesungguhnya ini merupakan tanggung jawab semua pihak, yaitu Pemerintah dan masyarakat. Jika dilihat dari prespektif Antropologi hukum, bahasa tana ini perlu mendapatkan perlindungan hukum agar tidak mengalami kepunahan secara keseluruhan. Pelindungan terhadap bahasa daerah didasarkan pada amanat Pasal 32 Ayat 2 UUD 1945, yang menyatakan bahwa negara menghormati dan memelihara bahasa daerah sebagai kekayaan budaya nasional. Dengan ayat itu, negara memberi kesempatan dan keleluasaan kepada masyarakat untuk melestarikan dan mengembangkan bahasanya sebagai bagian dari kebudayaannya masing-masing. Selain itu, negara memajukan kebudayaan nasional Indonesia di tengah peradaban

\footnotetext{
${ }^{8}$ Son Of Alifuru, “Bahasa Tana Bahasa Ibu orang Maluku”, Juliansupit blogspot.com/2011/03/bahasa-tana-bahasaibu-orang-maluku.html, (diakses 29 Juni 2017).

${ }^{9}$ Ibid.

${ }^{10}$ Purwaningsih, E. (2012). Partisipasi Masyarakat dalam Perlindungan Hukum terhadap Kekayaan Intelektual Warisan Bangsa. Masalah-Masalah Hukum, 41(1), h.43.
} 
dunia dengan menjamin kebebasan masyarakat dalam memelihara dan mengembangkan nilai-nilai budayanya.

Berdasarkan amanat pasal 32 ayat 2 UUD 1945 diatas, maka sangatlah diperlukan instrumen hukum yang secara nasional dapat memberi perlindungan bagi bahasa daerah. Jika dilindungi dengan aturan daerah, maka ketika ada aturan nasional maka runtuhlah aturan daerah itu. Lagi pula tidak semua daerah memiliki peraturan perlindungan terhadap bahasa daerah, termasuk propinsi Maluku. Dengan dikeluarkannya Undang-Undang Nomor 24 Tahun 2009 tentang Bendera, Bahasa, Lambang Negara serta Lagu Kebangsaan sesungguhnya menjadi payung hukum untuk perlindungan, pelestarian dan pembinaan bahasa daerah. Pemerintah daerah wajib mengembangkan, membina, dan melindungi bahasa dan sastra daerah agar tetap memenuhi kedudukan dan fungsinya dalam kehidupan bermasyarakat sesuai dengan perkembangan zaman dan agar tetap menjadi bagian dari kekayaan budaya Indonesia (pasal 42 ayat 1). Pengembangan, pembinaan dan perlindungan itu dilakukan secara bertahap, sistematis, dan berkelanjutan oleh pemerintah daerah di bawah koordinasi lembaga kebahasaan (pasal 42 ayat 2).

Dalam Peraturan Pemerintah Nomor 57 Tahun 2014 tentang pengembangan, Pembinaan dan Perlindungan Bahasa dan Sastra serta peningkatan fungsi bahasa Indonesia juga dijelaskan bahwa bahasa daerah memiliki fungsi yang sangat besar diantaranya sebagai pembentuk kepribadian suku bangsa, peneguh jati diri kedaerahan, sarana pengungkapan serta pengembangan sastra dan budaya daerah dalam bingkai keindonesiaan. Selain itu juga berfungsi sebagai sarana komunikasi dalam keluarga dan masyarakat daerah, bahasa media masa lokal dan sarana pendukung bahasa Indonesia serta sumber pengembangan bahasa Indonesia.

Terkait dengan hal itu, maka di Maluku harus perlu dilakukan penguatan-penguatan terhadap eksistensi penggunaan bahasa tana agar tidak mengalami kepunahan walaupun terjadi urbanisasi ataupun perkawinan antar etnik, yaitu melalui upaya perlindungan hukum. Berdasarkan latar belakang yang telah dikemukakan di atas maka judul dari penelitian ini adalah "Penguatan Eksistensi Bahasa Tana Dalam Upaya Perlindungan Hukum Bahasa Daerah Sebagai Warisan Budaya Bangsa"

\subsection{Rumusan Masalah}

Bagaimana meningkatkan penguatan eksistensi bahasa tana sebagai upaya perlindungan hukum terhadap bahasa daerah?

\subsection{Tujuan Penelitian}

Untuk mengetahui perlindungan hukum terhadap bahasa daerah melalui penguatan eksistensi bahasa tana Maluku sebagai warisan budaya bangsa.

\section{METODE PENELITIAN}

A. Jenis Penelitian

Penelitian ini termasuk dalam jenis penelitian yuridis normatif, yaitu suatu penelitian yang terutama mengkaji bahan-bahan hukum, ketentuan-ketentuan hukum positif, asas-asas hukum, prinsip-prinsip hukum maupun doktrin hukum guna menjawab isu hukum yang dihadapi. ${ }^{11}$ Bahan-bahan itu disusun secara sistimatis, dikaji, kemudian ditarik suatu kesimpulan dalam hubungannya dengan masalah yang diteliti.

B. Sifat Penelitian

Sifat penelitian yang digunakan adalah deskriptif analitis, yaitu dengan menggambarkan serta menguraikan semua data yang diperoleh dari hasil penelitian

\footnotetext{
${ }^{11}$ Supranto,j. (2003). Metode Penelitian dan Statistik. Jakarta : Rineka Cipta.h.3.
} 
yang berkaitan dengan judul penelitian hukum secara jelas dan rinci, kemudian dianalisis guna menjawab permasalahan yang diteliti. ${ }^{12}$ Adapun menurut Soerjono Soekanto, suatu penelitian deskriptif dimaksudkan untuk memberikan data yang seteliti mungkin tentang manusia keadaan atau gejala-gejala lainnya. ${ }^{13}$

C. Pendekatan Masalah

- Pendekatan Perundang-undangan (the statute approach)

Pendekatan Perundang-undangan (the statute approach) adalah pendekatan yang dilakukan dengan menelaah semua peraturan perundang-undangan dan regulasi yang bersangkut paut dengan isu hukum yang dihadapi. ${ }^{14}$

- Pendekatan konseptual (conceptual approach)

Pada pendekatan konseptual (conceptual Approach) beranjak dari pandanganpandangan dan doktrin-doktrin serta konsep dari bahan hukum yang berkembang di dalam ilmu hukum. Dengan mempelajari pandangan-pandangan dan doktrindoktrin di dalam ilmu hukum, peneliti akan menemukan ide-ide yang melahirkan pengertian-pengertian hukum, dan asas-asas hukum relevan dengan isu yang dihadapi.

D. Sumber Bahan Hukum

- Bahan hukum primer adalah bahan hukum yang mengikat terkait dengan Bahasa Daerah yaitu: UUD NRI 1945, Undang-Undang Nomor 24 Tahun 2009 tentang Bendera, Bahasa, Lambang Negara serta Lagu Kebangsaan, Peraturan Pemerintah Nomor 57 Tahun 2014 tentang pengembangan, Pembinaan dan Perlindungan Bahasa dan Sastra serta peningkatan fungsi bahasa Indonesia.

- Bahan hukum sekunder adalah bahan hukum yang memberikan penjelasan mengenai bahan hukum primer, yaitu bahan ilmiah (buku-buku), doktri para ahli serta wacana atau artikel di internet yang berhubungan dengan masalah terkait.

- Bahan hukum tertier yaitu bahan hukum yang memberikan petunjuk atau penjelasan terhadap bahan hukum primer dan bahan hukum sekunder, misalnya kamus hukum dan ensiklopedia.

E. Teknik Pengumpulan Bahan Hukum

Penelitian ini dilakukan dalam dua tahap yaitu meliputi

- Metode penelitian kepustakaan (library research)

Dalam metode penelitian kepustakaan ini yang dilakukan yaitu mempelajari dan membaca buku-buku, media cetak lainnya dan peraturan perundang-undangan yang terkait dengan penelitian yang dilakukan. Studi kepustakaan dilakukan untuk dapat mengetahui lebih banyak pendapat para ahli yang terlebih dahulu melakukan penulisan yang berkaitan dengan penelitian yang dibuat

- Metode penelitian lapangan (fielt research)

Metode penelitian lapangan bertujuan untuk memberikan nilai tambah, dimana hasil penelitian kepustakaan tersebut akan dilengkapi dengan hasil wawancara maupun hasil pengamatan atau observasi.

\footnotetext{
${ }^{12}$ Waluyo, Bambang. (1991). Penelitian Hukum, Jakarta : Sinar grafika, h.8.

${ }^{13}$ Atsar, Abdul. (2017). Perlindungan Hukum Terhadap Pengetahuan dan Ekspresi Budaya Tradisional Untuk Meningkatkan Kesejahteraan Masyarakat Ditinjau Dari Undang-Undang No. 5 Tahun 2017 Tentang Pemajuan Kebdayaan dan Undang-Undang No. 28 Tahun 2014 Tentang Hak Cipta.. Jurnal Law Reform, 13(2), h. 288.

${ }^{14}$ Ibrahim, Jhony. (2012). Teori dan Metodologi Penulisan Hukum Normatif, Malang : Banyumedia Publishing, h.72.
} 
F. Teknik Analisa Bahan Hukum

Analisa bahan hukum dilakukan secara kualitatif mengingat bahan hukum yang terkumpul bersifat deskriptif. Sasuai dengan tujuan yang telah ditetapkan, maka analisi kualitatif ini berusaha untuk menghubungkan fakta yang ada dengan berbagai peraturan yang berlaku dan berhubungan dengan penelitian yang dibuat.

\section{Hasil dan Pembahasan}

3.1 Gambaran umum Penggunaan Bahasa Tana Sebagai Bahasa Daerah Di Maluku Maluku sebagai propinsi kepulauan sangat kaya dengan begitu banyaknya warisan budaya sebagai peninggalan para leluhur. Diantaranya adalah penggunaan bahasa tana sebagai salah satu sarana komunikasi dalam kehidupan sehari-hari maupun dalam acara-acara ritual kedaerahan. Seiring perkembangan zaman, penggunaan bahasa tana di Maluku sudah mulai terlupakan. Hal ini terjadi karena faktor urbanisasi, dimana begitu banyak pendatang-pendatang yang tinggal dan menetap di Maluku. Tujuan mereka pada umumnya adalah berdagang.

Bahasa yang pada umumnya dipakai di Maluku adalah bahasa melayu ambon. Bahasa melayu ambon dipakai pada zaman dulu diperkuat oleh orang Belanda untuk membedakan mereka dengan pribumi pada masa penjajahan. Pada saat itu ketika orang-orang masuk untuk beribadah ke Gereja mereka tidak boleh menggunakan bahasa daerah, sehingga kepercayaan animisme semakin termarjinalkan.

Berdasarkan hasil penelitian yang dilakukan oleh peneliti maka, hal-hal penting yang dapat ditemukan dari berbagai narasumber sebagai bahan analisa dalam penelitian ini adalah:

\section{a. Kantor Bahasa Propinsi Maluku ${ }^{15}$}

Kantor Bahasa Propinsi Maluku memiliki peranan penting dan tanggung jawab yang besar dalam mengupayakan pelestarian nilai-nilai budaya bangsa yang lebih khususnya adalah pelestarian bahasa daerah. Berdasarkan hasil wawancara dengan Kepala Kantor Bahasa Propinsi Maluku, Bapak Asrif maka dapat diketahui langkahlangkah yang telah ditempuh oleh institusi tersebut dalam upaya menghidupkan kembali bahasa daerah di Maluku.

Salah satu program kerja Kantor Bahasa yang dilakukan setiap tahunnya mulai dari tahun 2012 adalah Kampanye Tentang Penguatan Bahasa Daerah, dengan mengangkat Duta Bahasa yang tugasnya menyampaikan dan mempublikasikan pentingnya pelestarian bahasa daerah. Kampanye yang dilakukan berpusat pada masyarakat umum dan lembaga-lembaga pendidikan di tingkat SD, SMP, SMA dan perguruan tinggi. Slogan yang mereka pakai adalah: " Utamakan Bahasa Indonesia, Lestarikan Bahasa Daerah, Kuasai Bahasa Asing". Program yang dijalankan oleh Kantor Bahasa Propinsi Maluku ini sangat membantu pemerintah dalam upaya melestarikan bahasa daerah. Walaupun pemerintah belum serius dalam upaya pelestarian bahasa baerah. Melalui program ini Kantor Bahasa Propinsi Maluku mewajibkan di setiap sekolahsekolah dalam mata pelajaran muatan lokal untuk mengajarkan bahasa daerah atau mempergunakan bahasa daerah dalam proses belajar-mengajar disamping menggunakan bahasa Indonesia. Menurut kepala Kantor Bahasa Propinsi Maluku Bapak Asrif, bahwa sasaran mereka selain kepada masyarakat umum, mereka ingin memperkenalkan bahasa daerah itu juga kepada anak-anak.

${ }^{15}$ Wawancara dengan BapakAsrif, Kepala Kantor Bahasa Propinsi Maluku, tanggal 29 November 2017. 
Berdasarkan hasil penelitian yang dilakukan oleh Kantor Bahasa Propinsi Maluku maka dari beberapa daerah yang menjadi lokasi penelitian Kantor Bahasa Propinsi Maluku yaitu Seram, Buru dan Maluku Tenggara, maka pulau seram yang sudah banyak teridentifikasi penggunaan bahasa daerahnya. Ternyata di Pulau Seram, daerah bagian pegunungan masih mempertahankan penggunaan bahasa daerah dibandingkan daerah bagian dataran bawah. Maluku Tenggara adalah salah satu daerah yang tetap mempertahankan penggunaan bahasa daerah. Hal ini terbukti, dimana saja orang Maluku Tenggara berada, mereka tetap mempergunakan bahasa daerah, baik itu komunikasi sehari-hari dalam keluarga maupun dalam acara-acara ritual adat.

Pada tahun 2015, Kantor Bahasa Propinsi Maluku juga melakukan identifikasi bahasa daerah di pulau Haruku. Selama 600 tahun masyarakat di pulau Haruku telah menggunakan bahasa daerah. Namun begitu banyak kendala yang dihadapi oleh Kantor Bahasa Propinsi Maluku maka identifikasi yang dilakukan gagal.

\section{b. Balai Pelestarian Sejarah Dan Nilai Tradisional Ambon ${ }^{16}$}

Bahasa tana secara keseluruhan dibedakan karena kultur atau budaya. Bahasa tana di Maluku, berbeda dengan bahasa tana di maluku tengah, maluku barat daya dan maluku tenggara. Maluku tengah lebih dikenal dengan bahasa tana-nya yang disebut "kapata", Maluku dikenal dengan bahasa tana "ulutan salawanda".

Bahasa tana itu mengkisahkan sebuah perjalanan, sejarah, atau simbol yang bisa menjelaskan sesuatu, misalnya suatu kedatangan, menjelaskan suku, campuran budaya, solidaritas, dan ikatan. Ketika kita berbicara sesuatu dengan menggunakan bahasa daerah, orang yang mendengar pembicaraan kita mereka langsung refleks karena ada ikatan wilayah. Tetapi sekarang banyak bahasa yang sudah tercampur dengan bahasa lain. Misalnya, di daerah Piru, banyak tercampur dengan bahasa Jawa, Buton yang merupakan bahasa dari masyarakat pendatang.

Penggunaan bahasa tana menunjukkan identitas dari suatu kultur atau budaya. Oleh karena itu bahasa tana sangat penting untuk tetap dilestarikan, karena setiap acara ritual pelaksanaan budaya lokal, semuanya dilakukan dengan menggunakan bahasa tana (pasawari). Bahasa secara struktur dia mengangkat, tetapi secara kultur memiliki hubungan emosional antara sesamanya melampaui batas-batas wilayahnya. Di Maluku Tenggara Barat, bahasa tana disebut "Tiarlea" (pantun yang dinyanyikan oleh masyarakat Maluku Tenggara Barat). Pantun tersebut mengisahkan perjalanan moyang-moyang di Maluku Tenggara Barat.

Berdasarkan hasil penelitian yang dilakukan oleh Balai Pelestarian Sejarah dan Nilai Tradisional Ambon, banyak bahasa tana yang tidak teridentifikasi atau terinventarisir karena disebabkan oleh faktor urbanisasi dimana masyarakat pendatang dari luar Maluku hidup bercampur dengan masyarakat asli dan mereka tetap menggunakan bahasa mereka juga. Penggunaan bahasa tana dari generasi ke generasi mulai hilang karena tidak dipergunakan lagi.

\section{c. Negri Hitu dan Dusun Airpessy, Desa Piru17}

Penggunaan bahasa tana di negeri Hitu hanya pada saat acara-acara ritual adat saja. Negeri Hitu merupakan salah satu negeri binaan dari Kantor Bahasa Propinsi Maluku.

\footnotetext{
${ }^{16}$ Wawancara dengan Bapak Marten Pattipeilohy, peneliti pada Balai Pelestarian Sejarah dan Nilai Tradisional Ambon, tanggal 6 Desember 2017.

${ }^{17}$ Wawancara dengan Raja Negeri Hitu dan Kepala Dusun Airpessy, Desa Piru.
} 
Kesadaran masyarakat di negeri Hitu akan pentingnya bahasa tana mulai bertumbuh dan berkembang ketika mereka menyadari bahwa anak-anak mereka tidak tahu bahkan tidak menggunakan bahasa tana dalam percakapan sehari-hari. Anak-anak SD, SMP dan SMP hanya mengetahui sapaan yang umum-umum saja, selebih dari itu tidak.

Oleh karena itu pemerintah negeri Hitu bekerjasama dengan Kantor Bahasa Propinsi Maluku membuat pelestarian ulang bahasa tana dengan membuat lomba-lomba berupa festival bahasa daerah dalam bentuk pentas drama. Program ini termasuk berhasil dan sukses dijalankan di negeri Hitu. Selain itu juga, ada program rutin yang dilaksanakan yaitu "wajib berbahasa daerah pada setiap hari minggu". Kenapa hari minggu? Karena pada hari minggu-lah semua orang yang beraktivitas di luar negeri Hitu, kembali pulang berkumpul dengan sanak saudara. Kewajiban penggunaan bahasa daerah ini harus dipatuhi oleh semua orang, sebab ada sanksi yang dapat dikenakan bagi mereka yang tidak menggunakan bahasa daerah pada hari minggu. Sanksi itu antara lain: mencuci piring, menyapu halaman rumah dan sanksi lainnya.

Hal ini dilakukan oleh pemerintah negeri Hitu agar bahasa daerah mereka tetap lestari, tidak punah, dan akan tetap terus dipakai sebagai alat komunikasi yang mempersatukan mereka, walaupun ada diantara mereka nantinya yang akan merantau ke daerah lain. Dengan bahasa daerah, mereka akan tetap saling mengenal.

Lain halnya di Dusun Airpessy, Desa Piru. Nama Airpessy adalah nama yang baru, sedangkan nama yang lama adalah Lopessy. Dusun ini didiami bukan lagi oleh orang asli pulau Seram karena yang ada sekarang adalah orang Buton yang asal muasalnya adalah orang asli dari Sulawesi Tenggara. Terkait keberadaan orang asli Dusun Airpessy tidak diketahui karena orang-orang buton yang mendiami dusun Airpessy sekarang beranggapan merekalah orang asli dusun tersebut karena sudah sangat lama mereka mendiami dusun Airpessy.

Terkait dengan bahasa daerah yang digunakan, sudah jelas bahwa mereka tidak menggunakan bahasa daerah asli dusun Airpessy yang dulunya bernama dusun Lopessy. Yang mereka gunakan adalah bahasa asli mereka yaitu bahasa buton. Bahasa buton masih digunakan di dusun Airpessy tetapi hanya digunakan oleh orang-orang yang sudah tua. Dikalangan anak-anak muda dan anak-anak kecil bahasa buton sudah tidak menggunakan bahasa buton dalam pergaulan mereka sehari-hari. Bahasa buton ini tidak juga digunakan sehari-hari tetapi hanya di saat-saat dimana ada hal-hal yang menurut mereka penting barulah mereka menggunakan bahasa Buton, dan itu juga tidak boleh diketahui oleh orang dagang atau orang pendatang. Dusun Airpessy ini berada di Desa Piru, Kecamatan Seram Barat Kabupaten Sram Bagian Barat.

\subsection{Penguatan Eksistensi Bahasa Tana Dalam Upaya Perlindungan Hukum Bahasa Daerah Sebagai Warisan Budaya Bangsa}

Menurut Keraf sebagaimana yang dikutip oleh Ahmad Nasir Biasane, ${ }^{18}$ Kearifan lokal adalah semua bentuk pengetahuan, keyakinan, pemahaman atau wawasan serta adat kebiasaan atau etika yang menuntun perilaku manusia dalam kehidupan di dalam komunitas ekologis. Sehingga kearifan lokal bukan hanya menyangkut pengetahuan atau pemahaman masyarakat adat tentang manusia dan bagaimana relasi yang baik diantara manusia, melainkan juga menyangkut pengetahuan, pemahaman, adat kebiasaan tentang manusia, alam dan bagaimana relasi diantara semua penghuni

\footnotetext{
${ }^{18}$ Biasane, A.N. (2004). Kontruksi Kearifan Tradisional Dalam Pengelolaan Perikanan Berkelanjutan, Makalah Pengantar ke Filsafat Sains Sekolah Pasca Sarjana/S3, Institut Pertanian Bogor.h.3.
} 
komunitas ekologi. Seluruh kearifan lokal ini dihayati, dipraktikkan, diajarkan dan diwariskan dari satu generasi ke generasi lain yang sekaligus membentuk pola perilaku manusia sehari-hari, baik terhadap sesama manusia maupun terhadap alam dan yang gaib. Bahasa daerah dipakai untuk membangun relasi diantara semua penghuni suatu komunitas dalam kehidupan sehari-hari, bukan saja pada upacaraupacara adat atau acara adat istiadat lainnya.

Pelindungan terhadap bahasa daerah didasarkan pada amanat Pasal 32 Ayat (2) UUD 1945, yang menyatakan bahwa negara menghormati dan memelihara bahasa daerah sebagai kekayaan budaya nasional. Dengan ayat itu, negara memberi kesempatan dan keleluasaan kepada masyarakat untuk melestarikan dan mengembangkan bahasanya sebagai bagian dari kebudayaannya masing-masing. Selain itu, negara memajukan kebudayaan nasional Indonesia di tengah peradaban dunia dengan menjamin kebebasan masyarakat dalam memelihara dan mengembangkan nilai-nilai budayanya. Pemerintah mengeluarkan Undang-Undang Nomor 24 Tahun 2009 tentang Bendera, Bahasa, Lambang Negara serta Lagu Kebangsaan yang didalamnya mengatur pentingnya perlindungan, pelestarian dan pembinaan bahasa daerah. Undang-Undang Nomor 24 Tahun 2009 mendefinisikan bahasa daerah sebagai bahasa yang digunakan secara turun-temurun oleh warga negara Indonesia di daerah-daerah di Wilayah Negara Kesatuan Republik Indonesia. Dengan demikian, bahasa daerah diibaratkan sebagai jati diri masyarakat indonesia yang beragam suku.

Oleh karena bahasa daerah diibaratkan sebagai jati diri masyarakat Indonesia yang beragam suku maka menjadi tanggung jawab semua pihak untuk tetap memberikan perlindungan, pembinaan dan upaya pelestarian bahasa daerah. Perangkat aturan nasional telah terbentuk, oleh karena itu dapat menjadi dasar bagi pemerintah daerah, terkhususnya pemerintah daerah Propinsi Maluku untuk dapat memiliki peraturan perlindungan terhadap bahasa daerah.

Sampai saat ini Pemerintah Propinsi Maluku belum memiliki peraturan perlindungan terhadap bahasa daerah. Padahal dalam Undang-Undang Nomor 24 Tahun 2009 tentang Bendera, Bahasa, Lambang Negara serta Lagu Kebangsaan menyatakan: Pemerintah Daerah wajib mengembangkan, membina, dan melindungi bahasa dan sastra daerah agar tetap memenuhi kedudukan dan fungsinya dalam kehidupan bermasyarakat sesuai dengan perkembangan zaman dan agar tetap menjadi bagian dari kekayaan budaya Indonesia (pasal 42 ayat 1 ). Pengembangan, pembinaan dan perlindungan itu dilakukan secara bertahap, sistematis, dan berkelanjutan oleh pemerintah daerah di bawah koordinasi lembaga kebahasaan (pasal 42 ayat 2).

Selain itu juga dalam Peraturan Pemerintah Nomor 57 Tahun 2014 tentang pengembangan, Pembinaan dan Perlindungan Bahasa dan sastra serta peningkatan fungsi bahasa Indonesia juga menjelaskan bahwa bahasa daerah memiliki fungsi yang sangat besar diantaranya sebagai pembentuk kepribadian suku bangsa, peneguh jati diri kedaerahan, sarana pengungkapan serta pengembangan sastra dan budaya daerah dalam bingkai keindonesiaan. Selain itu juga berfungsi sebagai sarana komunikasi dalam keluarga dan masyarakat daerah, bahasa media masa lokal dan sarana pendukung bahasa Indonesia serta sumber pengembangan bahasa Indonesia.

Terkait dengan hal itu, maka di Maluku harus perlu dilakukan penguatan-penguatan terhadap eksistensi penggunaan bahasa tana agar tidak mengalami kepunahan walaupun terjadi urbanisasi ataupun perkawinan antar etnik, yaitu melalui upaya perlindungan hukum.

Upaya perlindungan hukum yang dapat ditempuh yaitu dengan membuat peraturan daerah (perda) yang secara khusus mengatur tentang perlindungan hukum terhadap 
bahasa daerah atau bahasa tana. Perda tersebut nantinya dapat menjadi dasar bagi upaya penguatan eksistensi bahasa tana di Maluku, antara lain:

1. Pemerintah daerah Propinsi Maluku dapat mewajibkan di setiap lembagalembaga pendidikan dari SD, SMP sampai SMA untuk memasukkan pelajaran khsusus tentang bahasa daerah atau bahasa tana dalam mata pelajaran muatan lokal.

2. Pemerintah Daerah Propinsi Maluku dapat mewajibkan penggunaan bahasa daerah atau bahasa tana baik dalam pergaulan sehari-hari maupun dalam pergaulan resmi lainnya.

3. Pemerintah Daerah Propinsi Maluku dapat mencanangkan hari penggunaan bahasa daerah.

4. Pemerintah Daerah Propinsi Maluku dapat mewajibakan semua negeri dan desa yang ada di Maluku untuk wajib menggunakan bahasa daerah atau bahasa tana disamping menggunakan bahasa nasional sebagai upaya pelestarian bahasa daerah atau bahasa tana.

Peranan Kantor Bahasa dan Balai Pelestarian Sejarah dan Nilai Tradisional Ambon yang ada di Propinsi Maluku sangatlah penting dalam melestarikan bahasa daerah atau bahasa tana. Kajian-kajian ilmiah yang dilakukan oleh Kantor Bahasa dan Balai Pelestarian Sejarah dan Nilai Tradisional Ambon yang ada di Propinsi Maluku adalah sumber data yang sangat akurat yang dapat menjadi dasar bagi Pemerintah Daerah Propinsi Maluku dalam mengambil kebijakan untuk membentuk Peraturan Daerah perlindungan bahasa daerah atau bahasa tana.

Peningkatan kesadaran penggunaan bahasa daerah atau bahasa tana oleh masyarakat Maluku akan semakin kuat jika ditunjang dengan seperangkat aturan hukum. Seperti di Negeri Hitu, kebijakan yang ditempuh oleh Raja dan Perangkat Negeri lainnya untuk mewajibkan semua orang di negeri Hitu untuk wajib menggunakan bahasa daerah atau bahasa tana pada hari minggu merupakan salah satu langkah yang baik sebagai upaya penguatan eksistensi penggunaan bahasa daerah atau bahasa tana, apalagi disertai dengan sanksi tegas bagi mereka yang tidak menggunakan bahasa daerah atau bahasa tana pada hari yang telah ditentukan. Kebijakan ini akhirnya harus mewajibkan semua orang tua di Negeri Hitu untuk mengajarkan bahasa daerah atau bahasa tana kepada anak-anak mereka. Kebijakan yang ditempuh oleh Raja dan Perangkat Negeri Hitu semestinya harus menjadi contoh untuk semua negeri dan desa yang ada di Maluku untuk tetap menggunakan bahasa daerah atau bahasa tana sebagai upaya melestarikan kearifan lokal atau budaya lokal yang menjadi bagian dari kebudayaan nasional.

\section{Kesimpulan}

Dari hasil penelitian dan pembahaan yang telah dipaparkan di atas maka kesimpulan yang didapat adalah eksistensi penggunaan bahasa daerah atau bahasa tana di Maluku sangatlah rendah atau bahkan ada yang sudah punah. Hingga sekarang tidak kurang dari 117 bahasa tana yang terdapat di seluruh Maluku, dan ada beberapa yang mengalami kepunahan. Di Maluku baru 48 bahasa daerah atau bahasa tana yang teridentifikasi masih eksis digunakan yaitu di daerah Hitu dan Maluku Tenggara.

Pasal 32 Ayat (2) UUD 1945, Undang-Undang Nomor 24 Tahun 2009 tentang Bendera, Bahasa, Lambang Negara serta Lagu Kebangsaan, dan Peraturan Pemerintah Nomor 57 Tahun 2014 tentang pengembangan, Pembinaan dan Perlindungan Bahasa dan sastra serta peningkatan fungsi bahasa Indonesia adalah dasar bagi Pemerintah Propinsi Maluku untuk melahirkan Peraturan Daerah untuk melindung bahasa daerah 
atau bahasa tana sebagai bentuk penguatan eksistensi penggunaan bahasa tana di Maluku.

Sebagai upaya penguatan eksistensi penggunaan bahasa daerah atau bahasa tana di Maluku maka yang diharapakan adalah:

1. Adanya kerjasama dan kordinasi yang baik antara Pemerintah Propinsi Maluku dengan Kantor Bahasa dan Balai Pelestarian Sejarah dan Nilai Tradisional Ambon terkait dengan pengumpulan data-data negeri dan desa yang masih menggunakan bahasa daerah atau bahasa tana atau yang sudah tidak lagi menggunakannya.

2. Adanya sebuah Peraturan Daerah (PERDA) sebagai dasar penguatan eksistensi penggunaan bahasa daerah atau bahasa tana di Maluku.

\section{Daftar Pustaka}

$\underline{\text { Buku }}$

Waluyo, Bambang. (1991). Penelitian Hukum. Jakarta : Sinar Grafika.

Supranto, J. (2003). Metode Penelitian Dan Statistik. Jakarta : Rineka Cipta.

Ibrahim, Jhony. Teori Dan Metodologi Penulisan Hukum Normatif. Malang : Banyumedia Publishing.

Hadjon, P,M. (2007). Perlindungan Hukum Bagi Rakyat Indonesia. Surabaya.

Soekanto, Soerjono. (1984). Pengantar Penelitian Hukum.Jakarta : Universitas Indonesia.

\section{Jurnal}

Tondo, H. (2009). Kepunahan Bahasa-Bahasa Daerah: Faktor Penyebab dan Implikasi Etnolinguistis. Jurnal Masyarakat dan Budaya, 11(2).

Endang, P. (2012). Perlindungan Hukum Terhadap Kekayaan Intelektual Warisan Bangsa Sebagai Implikasi Yuridis Nilai-Nilai Kebangsaan Menuju Ketahanan Nasional.

Purwaningsih, E. (2012). Partisipasi Masyarakat dalam Perlindungan Hukum terhadap Kekayaan Intelektual Warisan Bangsa. Masalah-Masalah Hukum, 26(3).

Islamuddin, I. (2016). Pengembangan Budaya Suku Talang Mamak Sebagai Nilai-Nilai Kearifan Lokal Dalam Bagian Civic culture (Studi Etnografi pada masyarakat suku Talang Mamak di Kecamatan Rakit Kulim, Kabupaten Indragiri Hulu, Propinsi Riau). Jurnal Pendidikan Ilmu Sosial, 23(2).

Atsar, A. (2017). Perlindungan Hukum Terhadap Pengetahuan Dan Ekspresi Budaya Tradisional Untuk Meningkatkan Kesejahteraan Masyarakat Ditinjau Dari Undang-Undang No. 5 Tahun 2017 Tentang Pemajuan Kebudayaan Dan Undang-Undang No. 28 Tahun 2014 Tentang Hak Cipta. Law Reform, 13(2). 


\section{Makalah}

Biasane, A.N. (2004). Kontruksi Kearifan Tradisional Dalam Pengelolaan Perikanan Berkelanjutan, Makalah Pengantar Ke Filsafat Sains Sekolah Pasca Sarjana/S3. Institut Pertanian Bogor.

\section{Internet}

Badan Pengembangan Dan Pembinaan Bahasa Kementerian Pendidikan Dan Kebuadayan, Perlindungan Bahasa Daerah Dalam Kerangka Kebijakan Nasional Kebahasaan, www.google.com.

Son Of Alifuru, Bahasa Tana Bahasa Ibu Orang Maluku, juliansupitblogspot,com/2011/03/bahasa-tana-bahasa-ibu-orang-maluku.html

Maluku Wikipedia Indonesia, Ensiklopedia Bebas, https://id.wikipedia.org/wiki/mal.

\section{Perundang-Undangan}

Undang-Undang Dasar Negara Republik Indonesia Tahun 1945

Undang-Undang Nomor 24 Tahun 2009 tentang Bendera, Bahasa, Lambang Negara serta Lagu Kebangsaan, Lembaran Negara Republik Indonesia Tahun 2009 Nomor 109, Tambahan Lembaran Negara Republik Indonesia Nomor 5035

Peraturan Pemerintah Nomor 57 Tahun 2014 tentang pengembangan, Pembinaan dan Perlindungan Bahasa dan sastra serta peningkatan fungsi bahasa Indonesia 